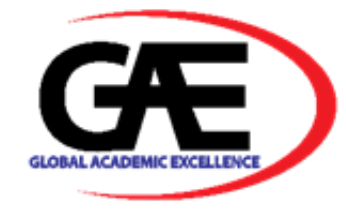

\title{
RIGHT OF ACCESS ON UNDERGROUND LAND DEVELOPMENT: GUIDANCE FROM SINGAPORE AND AUSTRALIA
}

\author{
Najah Inani Abdul Jalil ${ }^{1 *}$, Ain Husna Mohd Arshad ${ }^{2}$ \\ 1 School of Law, Universiti Utara Malaysia \\ Email: najah@uum.edu.my \\ 2 School of Law, Universiti Utara Malaysia \\ Email: ainhusna@uum.edu.my \\ Corresponding Author
}

\section{Article Info:}

Article history:

Received date: 09.11.2020

Revised date: 15.11 .2020

Accepted date: 10.12 .2020

Published date: 31.12 .2020

\section{To cite this document:}

Jalil, N. I. A., \& Arshad, A. H. M. (2020). Right of Access on Underground Land Development: Guidance From Singapore and Australia. International Journal of Law, Government and Communication, 5 (21), 267-276.

DOI: $10.35631 /$ IJLGC.5210022.

This work is licensed under $\underline{\mathrm{CC} B Y} 4.0$

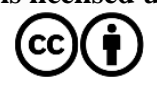

\begin{abstract}
:
In 1990, the creation of underground land is created in the National Land Code. The scarcity of land especially in urban areas has pushed the traditional horizontal land development into vertical land development. Apart from transportation purposes, it is suitable for recreational, storage, and service utility purposes. Within this development, it attracts questions such as how to reconcile the right of surface and underground landowners as the law has allowed the ownership of underground land to be independent and separate from the surface owner. In governing the relationship between the surface and the underground landowners, the provision of access, support, and protection are regulated under the express condition in the document of title. This paper explores the concept of the right of support in Malaysia and the requirement for its application. This paper uses the doctrinal method where statutory provisions, cases, legal articles are examined. In discussing this topic, the practice in Singapore and Australia is compared, and it is suggested in regulating the relationship between surface and underground landowners, the creation of easement to be adopted with the compensation to be awarded to the burdened land.
\end{abstract}

Keywords:

Access, Underground, Development, Easement, Acquisition, Stratum

\section{Introduction}

The scarcity of land has changed the traditional view on the horizontal surface development as the vertical underground development offers more practical solution especially in the urban area where the availability of land is limited (Jamalludin, Zaini, \& Hussin, 2016). Two factors Copyright $\odot$ GLOBAL ACADEMIC EXCELLENCE (M) SDN BHD - All rights reserved 


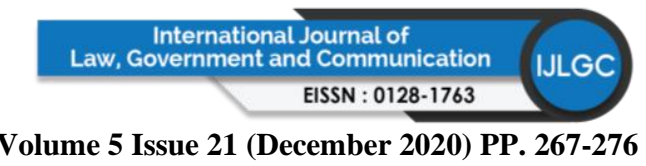

DOI 10.35631/IJLGC.5210022

contribute to an urban development which are global urbanization and growth of population, thereby increasing the demand for the use of urban underground space (Zargarian, Hunt, \& Rogers, 2013). Underground space is used for various function and it shall not be limited only for underground transportation. Its use shall be diversified and must be exploited effectively while preserving its safety. Two main functions are identified involving use of underground space. Firstly, functional infrastructure which supports the daily urban activities and maintain the smooth funning of resources within the cities. The examples are storage facilities, utility pipelines and energy exploitation system. Secondly, the underground space can be used for transportation and recreational arenas where human activities are carried out within a short period of time without intervening with the outer environment (Masuda Y., Takahashi N., 2004).

When use of land is changed from horizontal to vertical, there is a need for the traditional legal framework governing the changes to be legislated. The law must give effect to the transition of the two dimensional (2D) property rights legislation to the three dimensional (3D) property right legislation, hence harmonization of law can be achieved for the benefit of the community(Barker, 1991). Among the legal issues concerning 3D property are the right, responsibilities, and restriction of the surface and subjacent owners. The legal protection must be legislated at par with the technology of multi-storied building creating a new concept known as "earthscrapers"(Zhang, Paulsson, Gong, \& Huan, 2020). In comparison to the surface land, technology which makes underground development more viable is considered slow (Belyaev, 2016; Stones \& Heng, 2016).

There has been no comprehensive analysis on legal aspects concerning with the underground development as law always play a silent partner in property development. In the absence of supporting legal framework, the full potential of underground development may be hindered, slowed and abandoned. Underground space is a solution especially for urban area where land is constrained, but its development must be constructed with proper planning and supported with suitable legal framework. Hence, in managing the relationship between the surface and stratum owner, the law on right to support under the National Land Code Act 828 (hereinafter referred to as "NLC") plays important role. It provides for right of support of land in its natural state by any adjacent land. This is a negative right in which the adjacent owner is duty bound by the law to support the property of others and not to do something which will endanger his neighbours. The foundation for this concept is based on the theory that no land is selfsupporting. This paper intends to discuss the concept of underground land under the NLC. It begins with the discussion on the right of support in Malaysia and its application regarding the underground development. Practice from foreign countries such as Singapore and Australia are discussed, in which easement is adopted in reconciling the right and use of surface and underground landowner. In Singapore, an easement is created between the surface and subjacent owner without the need for registration, while in Australia, the court is granted with power to grant easement to parties.

\section{Underground Development in Malaysia}

The creation of underground land in Malaysia was introduced by the NLC under Part 5 entitled "Disposal of Underground Land" which make it possible for different uses of land at different level of the land. It must be noted that the NLC allows for separate use and ownership of surface and underground land. Hence, the surface land can be used for the residential purpose and its underground land can be used for the purpose of storage facilities and utility pipelines (Jalil, 2019). According section 92A NLC, an underground land means "land which lies below the 


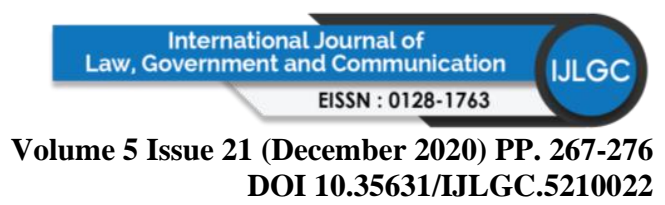

surface of the earth" while stratum means "a cubic layer of underground land", land identified for the use or purpose which is independence and irrelated to the surface land. The existence of stratum also allows the concept of adjoining underground land which means "underground land adjoining a stratum above, below and on the sides of the stratum". Disposition of underground land can be done using three ways. Firstly, through alienation (section 92C, section 92B(1)(a), section 92B (4), section 92(1)(b) and section 92B(1)(a) NLC). Secondly, through approval for independence and exclusive use (section 92(1)(a), section 92B(1)(a), section 92G and 92E (1) (a) NLC). Thirdly, through lease (section 92F(1)(a), section 92F(1)(b), section 92E (1)(a) and section 92E (3) NLC. According to National Land Code (Underground Land) Minimum Depth) Regulations 2017, the minimum depth as prescribed under section 92B NLC is as follows:

\begin{tabular}{|c|c|}
\hline $\begin{array}{c}\text { Description } \\
\text { (Category of Land) }\end{array}$ & $\begin{array}{c}\text { Minimum } \\
\text { Depth (metres) }\end{array}$ \\
\hline Agricultural & 6 \\
\hline Building & 10 \\
\hline Industry & 15 \\
\hline
\end{tabular}

Table 1: Minimum Depth of Underground Land in Malaysia

When an application for alienation of underground is approved in accordance with section $92 \mathrm{D}(1)(\mathrm{a})$ in which the use of underground land is independent and unrelated from the use of surface land, the approval shall be subjected to:

Section $92 \mathrm{D}(5)(\mathrm{b})$ of the NLC:

"such conditions as the State Authority may impose for the provision of protection and support to all or any land adjoining the alienated land in respect of which the approval is granted and to all adjoining underground land in relation to the underground land which is the subject of the approval, and for the provisions of access at one or more places, as the State Authority may specify, from all parts of the underground land to the surface of the alienated land, or otherwise as may be proposed by the applicant and approved by the State Authority, where, in the opinion of the State Authority, the nature of access of the use of the underground requires such access;"

Section 92D (5)(6) of the NLC

"Upon payment of the further premium, and the satisfaction of any other terms which may be required by the State Authority to be satisfied prior to the grant of the approval of the application, and upon acceptance in writing by the proprietor of all the matters and conditions under subsection (5) subject to which the application is approved, the State Authority shall endorse the approval and the conditions to which it is subject upon the document of title to the land, and the conditions under paragraph 5 (b), (c) and (d) shall, for all purposes under this Act, operate as express conditions, and the provisions of this Act relating to express conditions shall accordingly apply thereto" 


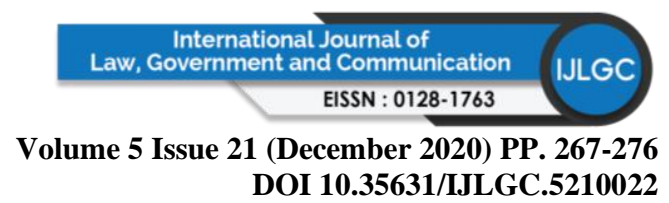

The issue which requires further consideration is on the right of access and support from the underground land to the surface land and vice versa (F.Zaini, K Hussin, NA Jamalludin, S Radioton, 2015; Kamal, 2011; Zaini, Hussin, \& Raid, 2017). Based on the sections above, the provision of protection, support and access for underground land shall operate and be endorsed as express condition to the land and the law relating to express conditions under the NLC shall apply. In The Ordinary Co Sdn Bhd v Lembaga Rayuan Negeri Selangor \& Anor [2014] 7 MLJ 705 , express condition is a condition that is attached to the land which is alienated by the state authority to a person or body. An express condition imposed on any land shall run with the land and binds the registered proprietor of the land. It becomes the duty of the registered proprietor to comply completely the land use and express condition imposed on his land and failure to comply will result the land be liable to be forfeited. In the event of inconsistencies between express condition and any restrictions imposed by the local authority or planning authority upon the owner of the land, the restriction shall not have any effect to the extent of the restriction is inconsistent with the express condition. Under the conditional land title, a system of control is introduced by defining landowner's proprietary rights, hence the right of a registered owner is limited which is evidenced by the imposition of categories, conditions and restriction in interest attached to the land. The category of land use imposed on a land will be of little explanation to the landowner. This absence is made good with the endorsement of express condition as well as automatic application of "implied condition" as set out in NLC, namely section 115 for agricultural land, section 116 for building land and section 117 for industrial land. (Awang, 1993). Furthermore, with endorsement of express condition, the owner is guided on what to do lawfully on his land. The power of the State Authority to impose these conditions, categories and restrictions in interest is provided for under section 120(1) NLC. It provides that:

"...the State Authority may alienate land under this Act subject to such express conditions and restrictions in interest conformable to law as it may think."

In this regard, a wide discretionary power is granted to the State Authority to impose conditions and restriction in interest on the land. The grant of wide discretionary power on the State Authority may lead to abuse of power as the latter is guided or depended on the political and socio-consideration existing at that time. The frequent changes of rules, regulations, and conditions created uncertainty and confusion thus impeding viable property developments (Awang, 1997).

\section{Right of Support under National Land Code Act 828}

The ancient maxim of "cujus est solum ejus es usque ad coelum et ad infernos" connotes the idea of exclusivity which does not limit the claim of ownership above the surface land and the soil beneath the surface land. Loosely translated, it means that the owner of the surface land owns the airspace above up to the limits of the atmosphere and the land below the surface land down to the centre of the earth. It did not impose any limitation or restrictions. Under the common law, this principle is used as governing the extent of ownership. However, the maxims have been historically confronted as the legality of common activities are questioned such the flying of aeroplanes and hanging of crane jibs over on another's land. In Malaysia, section 44(1)(a) NLC provides that:

"an owner has the exclusive use and enjoyment of so much of the column of airspace above the surface of the land and so much of the land below that surface as is reasonably necessary to the lawful use and enjoyment of the land," 


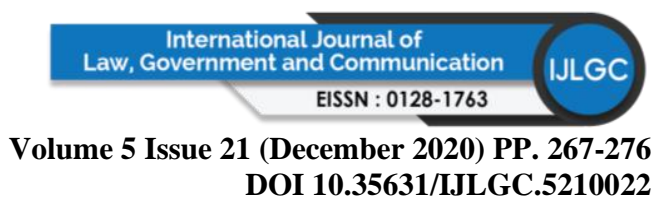

However, the restriction is illustrated in section 44 of the NLC where it provides that such rights must be exercised subject to the following limitations and restrictions. It is subject to qualifications under the modern Malaysian land tenure system where a person will not have absolute right only exclusive right on his lands against the third party. The exclusivity enjoyment of column of airspace and land below the surface under section 44 (1) (a) NLC is subjected to reasonably necessary to the lawful use and enjoyment of the land (Ainul Jaria, 2008). This does not mean that the owner does not has right at all on his land. The owner would have a dominant right of occupancy incidental to his ownership of property and he has right to prevent unreasonable interference with his enjoyment over his property. Section 44 (1) (a) NLC provides that the landowner, lessee, licensees under temporary occupation licence are entitled to the exclusive use and enjoyment of the land below the surface as is reasonably necessary to the lawful use and enjoyment of the land subject to the provisions of the law under the NLC and other written laws. The common law provides right to landowner to extend his right downright to prevent trespass by tunnelling under the surface land and the right to minerals.

Under the NLC, the common law of right of support by adjacent land has been encapsulated with statutory recognition under Section 44 (1) (b) NLC. Under this section, the right is given to the registered proprietor, lease holder and tenant to have support from adjoining land. However, the rights given are not absolute and unconditional subject to the reasonably necessary exclusive use and enjoyment of space above and below the land (Sivananthan a/l Krishan v Jade Homes Sdn Bhd \& Anor [2017] MLJU 2028). The land must be in natural state as the support would be statutorily required in its natural condition. However, the law would not sanction additional support if the land is in a weakened state. Upon disposal of the land, the right of support will be conferred to the owners and occupier of adjacent lands. This has been proven in Madam Chah Siam v Chop Choy Kong Kongsi (1939) MLJ 243. In this case, the court was in the opinion that no legal duty was created between plaintiff and defendants as the latter did not act outside the boundary of his leased mining land, nor he set free any object from his land as to cause damage to the plaintiff's land. According to the judgement, if there is no legal duty from the defendants to the plaintiff, then the defendants is at liberty to do anything within the boundaries of his land. The court was also in opinion that the doctrine of the right of lateral support to land will be granted to the occupants of the natural land, but not on a weakened or excavated land.

Similarly, in Guan Soon Tin Mining v Ampang Estate Ltd [1973] 1 MLJ 25 where the application of protection under section 44(1) (b) of the NLC is subject to the condition that the land is in its natural state. In this case, the cause of subsidence was not attributable to the current owner as the excavation of land have been executed by the predecessors. The new occupier or owner of the land is under no liability to pay damages if the damage is done due to his predecessors 'action. In Lembaga Air Perak $v$ Ding Keng Long \&Ors (Pentadbir Tanah Manjung \& Anor, Third Party)[2019] 8 MLJ 63 the land in question is entitled to have the right of support and the parties is entitled to damages when the excavation of red earth was carried out by the defendants which has resulted into immediate threat to the reservoirs. In Wong See Lee \& Ors v Ting Sik Ling [1997] 2 CLJ 205 in which the judge has explained as follows:

One form of natural rights is the right to support to from a neighbour's land.

It is 'natural' in the sense that it is an inseparable incident of property ownership. It is unlike an easement which must have been acquired by some kind of grant. The natural right is protected through the torts of nuisance and negligence. It is limited to the support of land in its natural state and does not apply to buildings on the land.

Copyright $\odot$ GLOBAL ACADEMIC EXCELLENCE (M) SDN BHD - All rights reserved 


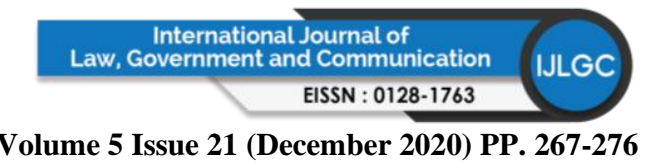

DOI 10.35631/IJLGC.5210022

Regarding the right of support to building, Dalton v Angus (1881) 6 Apps Cas 740 (stated that the right of support exists in the natural state of land as it is considered as an incident to the land itself. However, the right of support will not be accorded anymore when there are things artificially imposed or built on the land as the things do not exist naturally. Support for things exist non-naturally need to be acquired by grant because it imposes burden to the adjoining's land which naturally would be free from it. The differences of treatment accorded by law is due to the mode of acquiring them though the character of such right of supports when acquired are the same. In granting right of support to building, the landowner is restricted in terms of use of his own land, in the same manner as if he has given an easement which must be established by grant or prescription. There is no natural right of support for an owner to have additional weight of building on his land to be supported by the adjoining landowner. In the event where the support is withdrawn causing the land to subside (the subsidence was not caused by the additional weight of the buildings), the owner of the land is entitled to recover. Hence the owner of land is entitled to damages if his land has subsided by reason of excavation even though there is no building on the land.

From the discussion above, it shows the right of support is negative in its nature. It does not accord landowner a right of support from the adjoining property. The negative right merely gives right to the landowner if the existing support from the adjoining property has been interfered with or lost (Ainul Jaria, 2008). The archaic law relating to right of support from adjoining land need to be reformed as to avoid the incidence of subsidence and encroachment of land, especially in the underground development. This is necessary especially in underground development when both the surface and underground owners decide to simultaneously decide to develop their lands (Chew, 2017). The extent of availability of right of support and compensation to the affected parties must be addressed properly. The present law give rise to issues such as:

(i) If land subsides due to withdrawal of support from adjoining land, and the subsidence is not caused by any additional weight on the land.

(ii) Negligence by nearby (non-adjoining land) landowners.

(iii) Negligence by the landowner's contractor, engineer, or architect.

\section{Practice in Singapore: Easement of Underground Support}

Section 3C (1) of State Land Act (Chapter 314) (SLA) provides for the creation of easement of subjacent support for the benefit of the surface owner in respect of any parcel of land capable of providing with the subjacent support. To materialise the support for the surface owner, section 3C (2) allows for the installation or erection of structural support which may be constructed in subterranean space. In section 2 SLA, subterranean space is defined as "the subsoil below the surface of the earth". A cautionary statement is made in section 3C which states that a person entitled to the benefit of easement is prohibited to exercise his right "in a way that unreasonably prevents another person from enjoying the use and occupation of the other person's land", and be required to "take reasonable steps to minimise damage to land or other property". The application of easement under 3C of SLA will be exempted from the requirement of registration as in section 97 of Land Titles Act (Chapter 157) (LTA).

The amended section is to be in line with the decision in Xpress Prints $v$ Monocrafts Pte Ltd. [2000] $2 \operatorname{SLR}(R) 614$. According to this case, the right of support for the structures built on the land was based from the Latin maxim sic utere tuo ut alienum non ladas (to use your own property in such a manner as not to injure that of another). The right of support cannot be based Copyright (C) GLOBAL ACADEMIC EXCELLENCE (M) SDN BHD - All rights reserved 


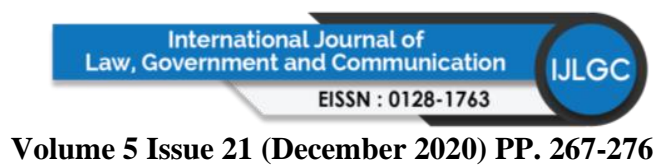

DOI 10.35631/IJLGC.5210022

exclusively on the theory of natural philosophy but must be viewed from the theory of reciprocity and mutual respect for each other's property. The right of support must be differentiated from the right of passage; and right to air and water as it raises different policy considerations. In case of right to support, upon its violation, it poses loss to life, property, and limb as the action for right of support cannot be instigated until the harm has occurred. In departing its decision from other Commonwealth cases, the learned judge held that the right of support in respect of a landowner's building from his adjoining land commences from the time such buildings are constructed. This view is compounded by the high use of all land in Singapore regardless it is used for the purpose of residential, commercial or industry. In enlarging the requirement of "natural state" in the original right of support, there is a correlating duty amongst adjoining landowners to secure alternative means of support if he intends to remove or excavate his land.

The practice in Singapore is to impose the use of easement of support to both the surface and subjacent landowners. Although the requirement of registration is waived, section 97A LTA provides for easement which is imposed by a court. Under this section, the court may order the easement if it satisfied that the benefit of the easement is consistent with the public interest, and the proprietor of land whom is to be burdened with the easement to be adequately compensated for any loss or disadvantages that may arise due to the creation of easement. The creation of easement which to give advantages to the dominant land should adequately be compensated with the compensation to be assessed by the third party.

\section{Practice in Australia: Power of court to impose easement}

In 1995, the New South Wales Parliament legislated section 88K Conveyancing Act 1919 with a view to enable the Supreme Court to grant easement over adjoining land if it is reasonably necessary for the effective use of any development. The main reason for such promulgation is to prevent the landowner neighbouring to the development site to hold ransom against the developer against the request of temporary easement (for example swinging crane) or permanent easement (for example drainage system). It also aims to avoid situations where neighbours intentionally block any development by refusing to give reasonable access right. In exercising its discretion in section 88K's application, the court may impose an easement which gives benefits to the dominant land and burdens the servient land, and requiring the landowner of the dominant land to pay compensation to the servient landowner.

Section $88 \mathrm{~K}$ of the Conveyancing Act

"(1) The Court may make an order imposing an easement over land if the easement is reasonably necessary for the effective use or development of other land that will have the benefit of the easement.

(2) Such an order may be made only if the Court is satisfied that:

(a) use of the land having the benefit of the easement will not be inconsistent with the public interest, and

(b) the owner of the land to be burdened by the easement and each other person having an estate or interest in that land that is evidenced by an instrument registered in the General Register of Deeds or the Register kept under the Real Property Act 1900 can be adequately compensated for any loss or other disadvantage that will arise from imposition of the easement, and

(c) all reasonable attempts have been made by the applicant for the order to obtain the easement or an easement having the same effect but have been unsuccessful. 


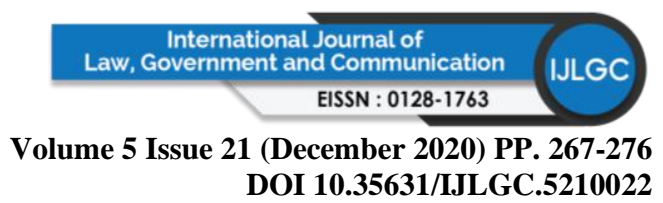

(3) The Court is to specify in the order the nature and terms of the easement and such of the particulars referred to in section 88 (1) (a)-(d) as are appropriate and is to identify its site by reference to a plan that is, or is capable of being, registered or recorded under Division 3 of Part 23. The terms may limit the times at which the easement applies.

(4) The Court is to provide in the order for payment by the applicant to specified persons of such compensation as the Court considers appropriate, unless the Court determines that compensation is not payable because of the special circumstances of the case".

In the case of ATB Morton Pty Ltd v Community Association DP270447 (No. 2) [2018] NSWLEC 87, the court will be guided by the following questions prior imposing easement:

(1) Whether the proposed easement is reasonably necessary for the effective use of the development in the dominant land?

(2) Whether the use of land in the dominant land be inconsistent with the public interest?

(3) Whether the neighbouring landowner can be adequately compensated for any loss or disadvantage due to the existence of easement?

(4) Whether the applicant has made all reasonable attempts to obtain an easement?

However, the court will not grant order of easement if there are alternative to the creation of easement which enable the development to proceed, although the alternative may cost more to the developer. Similarly, the court would be reluctant in exercising its discretion to grant easement if there is no specific evidence by the developer, its architect or planner to satisfy "reasonably necessary" test. Importantly, the owner of the burdened land can be adequately compensated for disadvantages and loss that will arise due to the easement. The court will determine the suitable amount of compensation unless it is decided that compensation is not payable due to the existence of special circumstances such as unreasonable conduct during negotiation or during the litigation.

\section{Conclusion}

The creation of underground land has been gazetted since 1990 and its use becoming more relevant especially with the advance of construction technology. The use of underground land attracts more questions as to what the owner of both surface and underground land can and cannot do due to its relationship physically. The current practice is to allow provision of access, support and protection to be captured under express condition. This paper is suggesting for the creation of easement of support between the parties and to allow the issue of cost and compensation to be made by the relevant authority. Possibly, during the exercise of right of support or access, the structure for support might go unnecessarily deep thereby trespassing the underground/or surface land. In Singapore, the relationship of both parties is regulated by the creation of easement where it is sanctioned by the State Land Act (Chapter 314). While it allows for the easement, the cautionary statement is made when each party has to reasonably exercise own's right or enjoyment. In Australia, although the creation of easement is not directly related to the underground development, it gives a new perspective where it gives the court a discretionary power to impose the creation of easement to the parties. The granting of easement is guided by the need to help the reasonable development of land while at the same time awarding the adequate compensation to be paid for any erosion of private right. It is also 


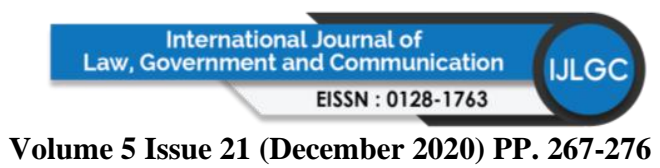

DOI 10.35631/IJLGC.5210022

suggested that the application for compensation can be made within a period of time as some damage may take some time to become apparent.

\section{Acknowledgment}

The authors would like to give an acknowledgement to Universiti Utara Malaysia for funding this research project under Geran Penjanaan SO Code 13938.

\section{References}

Ainul Jaria. (2008). Principles of Malaysian Land Law. Kuala Lumpur: Malayan Law Journal Sdn Bhd.

Awang, A. (1993). Restriction on LAnd Ownership and Its Implication on Property Development in Malaysia. In Fourth Australasian Real Estate Educators' Conference Auckland University 26-28 January 1993 (pp. 1-8).

Awang, A. (1997). Land Conversion, Subdivision and Amalgamation. Buletin Geoinformasi, $1(1), 37-44$.

Barker, M. (1991). Legal and administrative issues in underground space use: a preliminary survey of ITA member nations. Tunnelling and Underground Space Technology, 6(2), 191-209. https://doi.org/https://doi.org/10.1016/0886-7798(91)90066-D

Belyaev, V. (2016). Underground Development as Part of the Strategy for Sustainable Spatial Development of the City of Moscow. Procedia Engineering, 165, 277-281. https://doi.org/https://doi.org/10.1016/j.proeng.2016.11.701

Chew, E. (2017). Digging deep Into the Ownership of Underground Space-Recent Chnages in Respect of Subterranean Land Use. Singapore Journal of Legal Studies, 1, 1-17.

F.Zaini, K Hussin, NA Jamalludin, S Radioton, A. Z. (2015). The Principle of Depth for Underground Land Development: A Review. Jurnal Teknologi, 75(10), 71-78.

Jalil, N. I. A. (2019). Reconciliation of Right to Easement between Surface and Stratum Owner in Underground Development in Malaysia. Ain Husna Mohd Arshad, 22(3), 1-5.

Jamalludin, N. A., Zaini, F., \& Hussin, K. (2016). Development of Underground Land in Malaysia: The Need for Master Plan of Urban Underground Land Development. In Procedia-Social and Behavioral Sciences (Vol. 219, pp. 394-400). Elsevier.

Kamal, M. N. (2011, September). Govt acting in good faith on MRT Land acquisition. The Star Online.

Masuda Y., Takahashi N., O. T. (2004). Utilization of Deep Underground Space in TokyoUrban Renewal with City's New Backbone Lifeline. In Council on Tall Buildings and Urban Habitat (pp. 449-452).

Stones, P., \& Heng, T. Y. (2016). Underground Space Development Key Planning Factors. Procedia Engineering, 165, 343-354. https://doi.org/https://doi.org/10.1016/j.proeng.2016.11.709

Zaini, F., Hussin, K., \& Raid, M. M. (2017). Legal considerations for urban underground space development in Malaysia. Underground Space, 2(4), 234-245. https://doi.org/https://doi.org/10.1016/j.undsp.2017.11.001

Zargarian, R., Hunt, D., \& Rogers, C. (2013). The role of underground space in a sustainable UK urban environment. In Proceedings of 13th World Conference of the Associated Research Centres for the Urban Underground Space (ACUUS), Marina Bay, Singapore (pp. 930-942).

Zhang, Z., Paulsson, J., Gong, J., \& Huan, J. (2020). Legal Framework of Urban Underground Space in China. Sustainability, 12(8297), 1-17. https://doi.org/10.3390/su12208297 


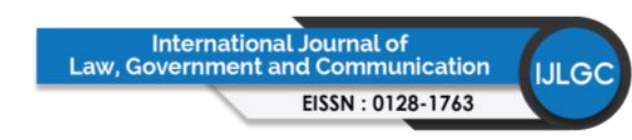

Volume 5 Issue 21 (December 2020) PP. 267-276

DOI 10.35631/IJLGC.5210022

The Ordinary Co Sdn Bhd v Lembaga Rayuan Negeri Selangor \& Anor [2014] 7 MLJ 705,

Sivananthan a/l Krishan v Jade Homes Sdn Bhd \& Anor [2017] MLJU 2028

Madam Chah Siam v Chop Choy Kong Kongsi (1939) MLJ 243

Guan Soon Tin Mining v Ampang Estate Ltd [1973] 1 MLJ 25

Lembaga Air Perak v Ding Keng Long \&Ors (Pentadbir Tanah Manjung \& Anor, Third Party)[2019] 8 MLJ 63

Dalton v Angus (1881) 6 Apps Cas 740

Wong See Lee \& Ors v Ting Sik Ling [1997] 2 CLJ 205

Xpress Prints v Monocrafts Pte Ltd [2000] 2 SLR (R) 614

ATB Morton Pty Ltd v Community Association DP270447 (No. 2) [2018] NSWLEC 87

National Land Code Act 828 (Revised 2020)

National Land Code (Underground Land) Minimum Depth) Regulations 2017

State Land Act (Chapter 314)

Land Titles Act (Chapter 157)

Conveyancing Act 1919 